\title{
Radical interstitial HDR brachytherapy in treatment of recurrent vulvar cancer: a case study
}

\section{Radykalna śródtkankowa brachyterapia HDR w leczeniu nawrotowego raka sromu. Opis przypadku}

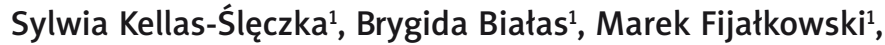 \\ Piotr Wojcieszek ${ }^{1}$, Marta Szlag ${ }^{2}$, Agnieszka Cholewka²
}

\author{
1Brachytherapy Department, M. Sklodowska-Curie Memorial Cancer Center and Institute of Oncology Gliwice Branch; \\ Head of Department: prof. dr hab. n. med. Bogusław Maciejewski \\ ${ }^{2}$ Department of Radiotherapy and Brachytherapy Planning, M. Sklodowska-Curie Memorial Cancer Center and Institute of Oncology \\ Gliwice Branch; \\ Head of Department: dr hab. n. fiz. Krzysztof Ślosarek
}

Przegląd Menopauzalny 2012; 4: 329-333

\section{Summary}

Background: Recurrences in vulvar cancer are a very important problem. It is estimated that even in multimodality treatment, about $10-20 \%$ of patients with the early stage and $50-70 \%$ with the advanced disease will develop recurrences. Interstitial High Dose Rate (HDR) Brachytherapy as a "boost" or as a sole treatment is one of the possible techniques in local failures in vulvar cancer therapy.

Case report: We report a case of a vulvar cancer local recurrence in a 90-year-old patient after primary surgery who was treated successfully and radically with interstitial HDR brachytherapy.

Conclusion: Interstitial HDR Brachytherapy in selected patients with a vulvar cancer local recurrence is an effective and safe method which allows to preserve organ functions with good cosmetic results.

Key words: interstitial HDR brachytherapy, vulvar cancer, local recurrence.

\section{Streszczenie}

Wstęp: Wznowy raka sromu stanowią poważny problem kliniczny. Szacuje się, że u ok. 10-20\% kobiet z wczesnym rakiem sromu oraz u 50-70\% z zaawansowaną chorobą wystąpi nawrót. Śródtkankowa brachyterapia HDR stosowana samodzielnie bądź jako „boost” jest jedną z metod leczenia w przypadku wznowy miejscowej raka sromu.

Przypadek: W pracy opisano przypadek 90-letniej chorej ze wznową miejscową raka sromu po leczeniu operacyjnym, u której zastosowano śródtkankową brachyterapię HDR.

Wniosek: Śródtkankowa brachyterapia HDR u wybranych chorych ze wznową miejscową raka sromu jest metodą skuteczną oraz bezpieczną, pozwalającą na zachowanie funkcji narządów.

Słowa kluczowe: śródtkankowa brachyterapia HDR, rak sromu, wznowa miejscowa.

\section{Introduction}

Vulvar cancer is one of the rarest gynaecological cancers [1, 2], but for last decades the number of new cases has increased, especially among young patients $[1,3,4]$. It accounts for $2-5 \%$ of all gynaecological carcinomas and about $0.6 \%$ of all malignant neoplasms in women $[1,5,6]$. Nowadays about $30 \%$ of patients who report with the advanced disease [5] are unable to undergo the standard treatment which is radical vulvectomy with inguinal lymph node dissection.

Recurrences in vulvar cancer are serious problems. Local failures are the most frequent while and groin recurrences are less common [6]. It is estimated that even in multimodality treatment, about $10-20 \%$ of patients with FIGO I and $50-70 \%$ with the advanced disease will recur [5, 7-9] and $40 \%$ of them will die [5]. 
Local failures may be successfully treated with surgery or radiotherapy, while patients with groin recurrences usually die $[6,10]$.

In the past, radiotherapy of vulvar cancers was less popular, e.g. because of frequent skin necrosis that limited the use of both external beam radiotherapy (EBRT) and brachytherapy. The orthovoltage X-rays gave a very high dose to skin, which is thin, delicate and highly vascularised in that region, causing troublesome and painful reactions [11]. Also brachytherapy was recommended as a method which should be used sparingly because of high morbidity in spite of its high effectiveness [12]. There is still an opinion that vulva is not a tissue that tolerates interstitial implants very well and tumours localized in that area are often not amenable to template guided implants [11].

In the Maria Sklodowska-Curie Memorial Cancer Center and Institute of Oncology Gliwice Branch interstitial HDR brachytherapy has been performed in selected patients with primary or recurrent vulvar cancer for twenty years. In patients who are not eligible for radical surgery or with the advanced or recurrent disease, that method is a proper treatment option offering good local control [13-15]. Nowadays, modern external beam radiotherapy and brachytherapy with advanced equipment and precise treatment planning, offers a highly conformal technique with a lower number of complications. Interstitial HDR brachytherapy delivers a high dose of radiation strictly to the tumour while sparing the adjacent healthy tissues. Due to the sensitive nature of the vulvar tissues, interstitial brachytherapy offers an effective, gentle and individualized therapy in a short time [9].

\section{Case report}

A 90-year-old woman with locally recurrent vulvar cancer was treated in the Maria Sklodowska-Curie Memorial Cancer Center and Institute of Oncology Gliwice Branch in 2005 and 2010 using interstitial HDR brachytherapy.

In 2000, at the age of 80 , she was diagnosed with a vulvar well differentiated squamous cell carcinoma with keratinization (G-1). Exophytic $2.5 \mathrm{~cm}$ tumour was

Tab. I. Details of the implant parameters

\begin{tabular}{lcc}
\hline & First HDR-BT & Second HDR-BT \\
\hline PTV & $4 \mathrm{~cm} \times 2.7 \mathrm{~cm} \times 1.5 \mathrm{~cm}$ & $3.7 \mathrm{~cm} \times 2.5 \mathrm{~cm} \times 1.4 \mathrm{~cm}$ \\
\hline V90 & $12.73 \mathrm{~cm}^{3}$ & $9.9 \mathrm{~cm}^{3}$ \\
\hline V100 & $10.82 \mathrm{~cm}^{3}$ & $8.46 \mathrm{~cm}^{3}$ \\
\hline V150 & $5.36 \mathrm{~cm}^{3}$ & $4.45 \mathrm{~cm}^{3}$ \\
\hline V200 & - & $2.5 \mathrm{~cm}^{3}$ \\
\hline PTV - planning target volume & \\
V90 (100, 150, 200) - target volume covered with 90\% isodose
\end{tabular}

localized on thr left large pudendal labia. Inguinal lymph nodes were not palpable, no other pathological changes were found. The patient was referred to a simple vulvectomy. The tumour was removed with some safety margins. After three months, an enlargement of left inguinal lymph nodes was observed. The left inguinal lymph node biopsy showed squamous cell carcinoma and inguinal lymphadenectomy was performed. The patient attended follow-up visits only for two years.

In 2005, on the left side of the vulvar scar, a $2-\mathrm{cm}$ recurrent tumour was noticed. No other pathological changes were found. The patient was referred to radical interstitial HDR brachytherapy.

In local anaesthesia three catheters were inserted into the tumour with a healthy tissue margin. The first session started on the same day after catheters' insertion.

The clinical target volume was determined either by clinical examination or CT imaging. The dose of interstitial HDR brachytherapy was prescribed $5 \mathrm{~mm}$ from the surface of applicator. Computerized optimization and three dimensional dose distribution were obtained using the PLATO System. HDR brachytherapy was performed with afterloading $\operatorname{~Ir~}^{192}$ source using microSelectron HDR (Nucletron). The total dose was 32Gy delivered twice a day with a 6 hours' break in fractionation dose 3.2Gy (Table I).

Just after the last fraction on the $5^{\text {th }}$ day (ten fractions), all catheters were removed. The healing process proceeded without any complications showing good tolerance of therapy.

Five weeks after the therapy the patient complained about itching and burning in the uro-genital area. In the tumour bed a $2 \mathrm{~cm}$ focus of epitheliolysis was noticed which healed in sequential follow-up visits.

Since 2008, the patient has stopped attending followup visits.

In February 2010, on the right side of a scar after vulvectomy, a local recurrence was noticed. The patient complained about an increasing discomfort and pain in vulva and perineum. On vulva there were two tumours: one on the right side of a scar after vulvectomy and the second in the area of posterior commissure of $2 \mathrm{~cm}$ and $0.5 \mathrm{~cm}$ in diameter, respectively. On the left side, in the area after previous brachytherapy, only a smooth scar with no evidence of recurrence was observed.

The patient was referred to the second radical interstitial HDR brachytherapy. In local anaesthesia three catheters (type: Comfort) were inserted into tumours with a safety margin. Fig. 1. The interstitial HDR brachytherapy schedule was the same as before (Fig. 2). The total dose was $31.5 \mathrm{~Gy}$ delivered twice a day with a 6 hours' break in fractionation dose 3.5Gy (nine fractions) (Table I).

After five days the catheters were removed. The healing process proceeded without any complications showing good tolerance of therapy. Only during the first 
days of therapy and about two weeks after the catheter removal, the patient reported itching and slight pain. There were visible superficial epitheliolysis and fibrin coat in examination in the treated area.

At present the patient is attending periodical follow-up visits. The inguinal lymph nodes were not oncologically suspicious in the ultrasound examination. In histopathology taken from the treated area there was only hyperplasia acanthotica with inflammatory cells.

\section{Discussion}

In recurrent vulvar cancer there is no standard treatment. A relatively low number of primary vulvar cancers with a low proportion of recurrences is the reason why it is difficult to perform randomized studies to document the most appropriate therapeutic modalities. In local failures, surgery or radiotherapy may be performed.

Radiotherapeutic management of recurrent vulvar cancer may incorporate interstitial brachytherapy as a part of the treatment, especially among patients disqualified from radical surgery $[11,16]$. Vulvar cancers, similarly to other squamous cell cancers, are very sensitive to radiation [10], but on the other hand, the vulvar skin tolerates radiotherapy poorly and toxicity limits its use $[13,17]$.

There are only few reports in the literature concerning recurrent vulvar cancer treated with interstitial HDR brachytherapy $[9,18,19]$. It may be used as a "boost" or as a sole treatment.

It is well documented that interstitial brachytherapy makes it possible to achieve a very good local control [9, $13,15,16,18,19]$. Jolicoeur described patients with early vulvar cancer (Tis, T1NOMO) and recurrent carcinoma (in situ) who were treated with interstitial HDR brachytherapy. The treatment scheme was similar to ours as regards the total doses (36 Gy) and the number of fractions (12). He obtained good results with a median follow-up of 30 months with disease-free survival and a survival rate of $98 \%$ and $100 \%$, respectively [18].
A

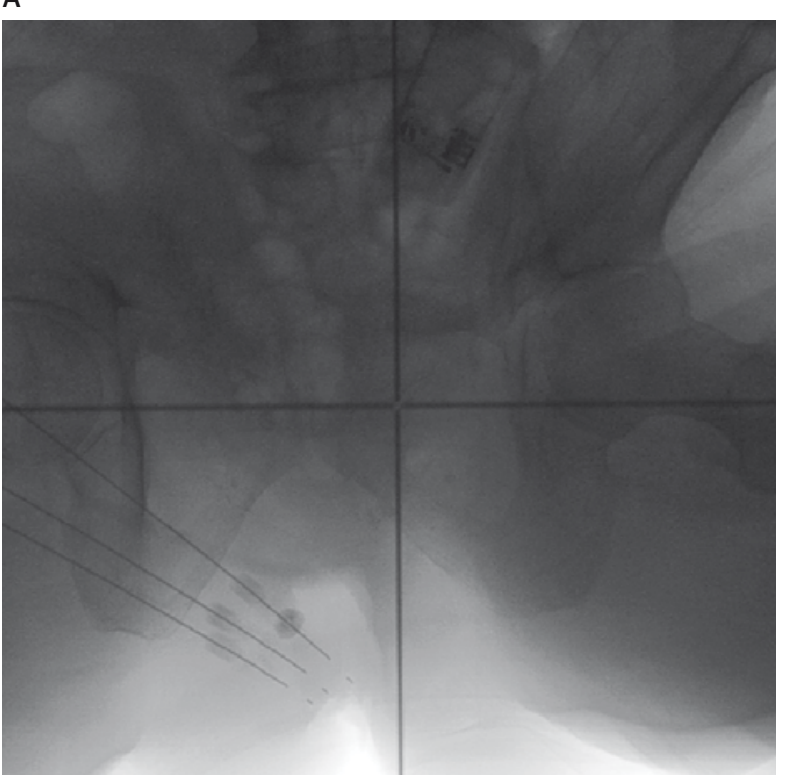

C

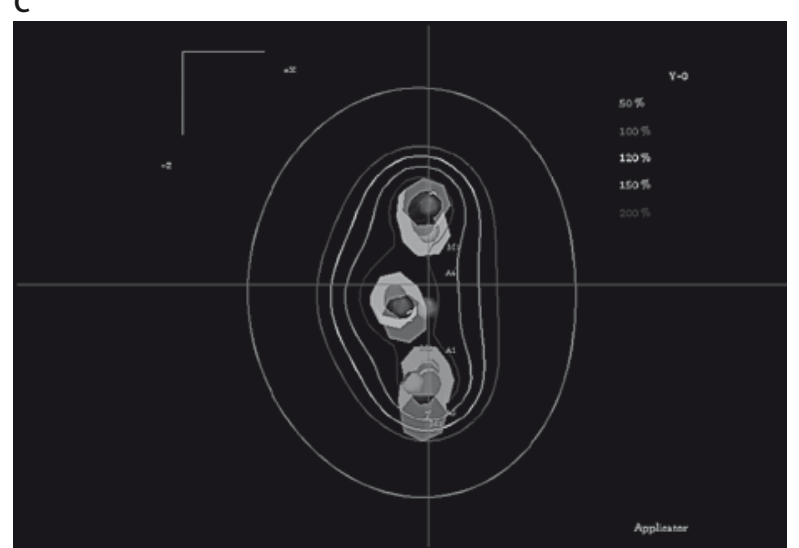

B

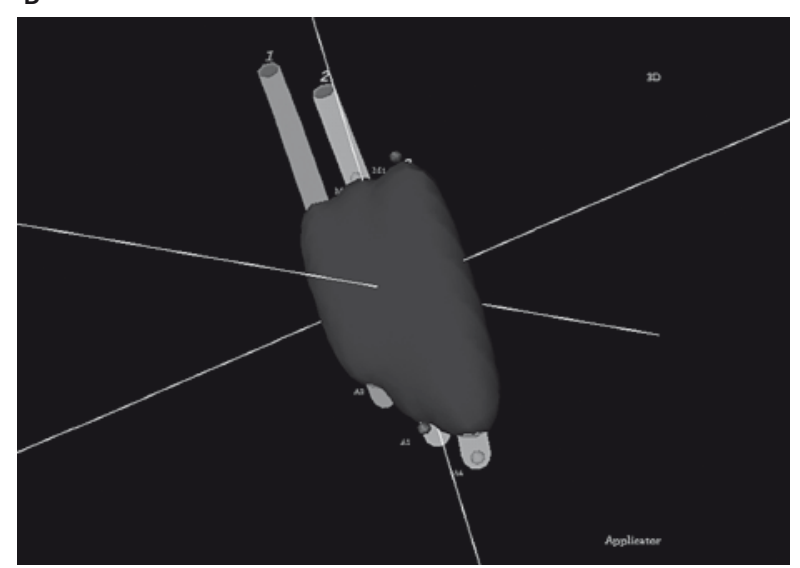

D

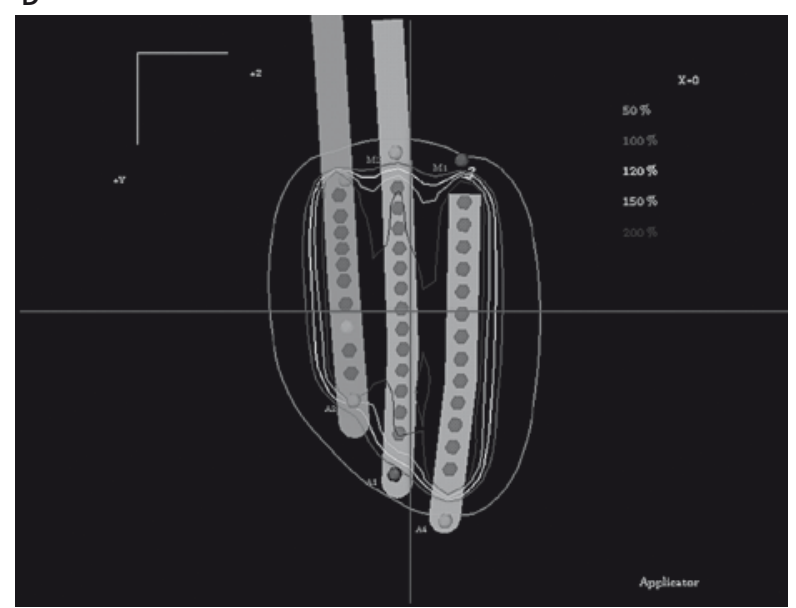

Fig. 1A-D. Interstitial high dose rate brachytherapy - treatment planning 
A

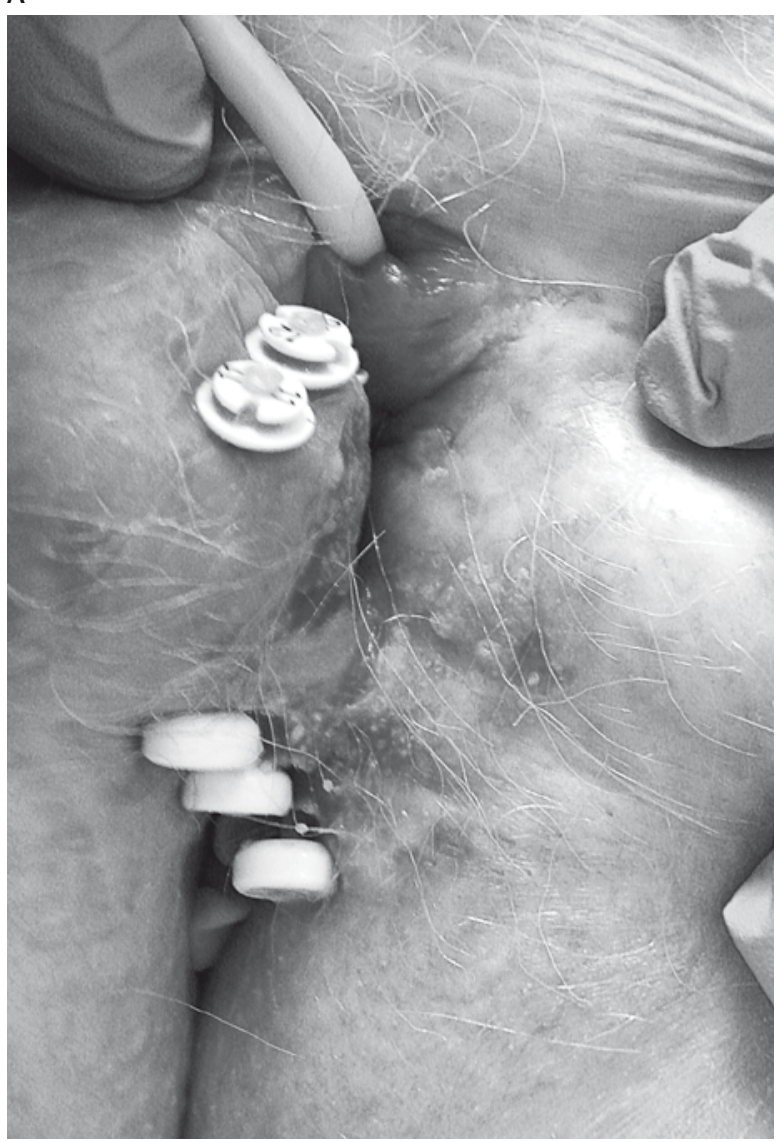

Fig. 2A-C. Interstitial high dose rate brachytherapy

Frezza also analyzed a group of patients with primary or recurrent vulvar cancer treated with brachytherapy. That group of patients was not eligble for a radical surgery and they were referred to adjuvant brachytherapy with or without EBRT. He reported brachytherapy alone or in combination with EBRT as a valid modality of therapy for selected patients not eligible for surgery [19].

Our patient has undergone radical interstitial HDR brachytherapy twice because of two local recurrences on vulva. The interstitial HDR Brachytherapy technique allowed us to use that method twice in one patient in areas which were localized on vulva very close to each other. After the first therapy we achieved a very good local control. The second failure occurred five years later on the opposite side of the vulva. In the last histopathology there were no tumour cells. The patient is under control but there are no symptoms of an active disease.

In our study interstitial HDR brachytherapy was tolerated very well; our patient had only acute complications. Other authors also observed a low number of complications $[9,14,18]$. Jolicoeur observed acute toxicity grade 2 in all patients but late severe toxicity only in two women [18].

In the literature, there is information that interstitial brachytherapy may cause severe toxicity $[11,12,15]$ and

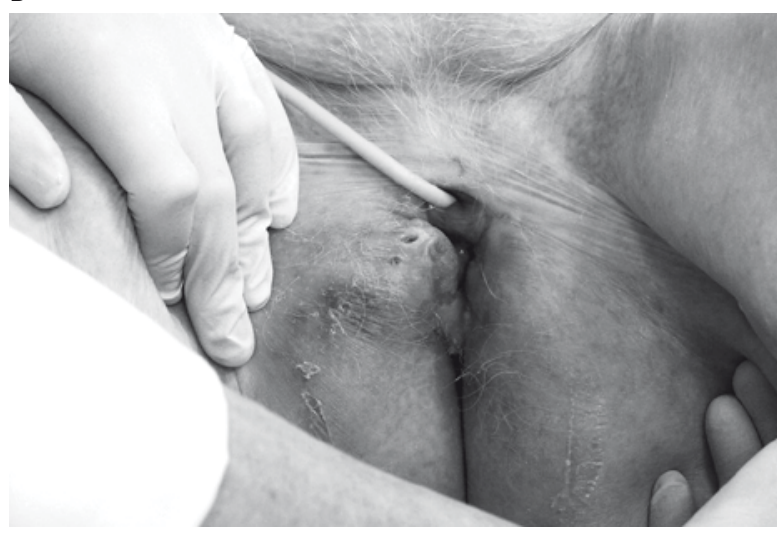

C

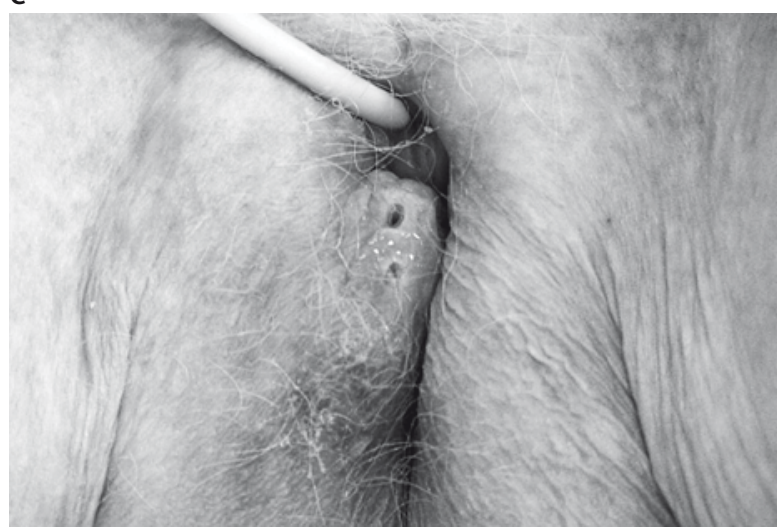

in our practice we also observed some severe treatment complications. A very important issue is a proper qualification to therapy, fractionation scheme and total dose to the tumour. We have our own scheme of fractionation and the dose per session is usually 3,5 Gy in the case of a vulvar cancer. In our opinion it is not only safe, but also effective. In the past, when the doses were a bit higher, we observed more complications. The total doses in the vulvar region depend on the treatment aim, but in radical therapy it is about $32 \mathrm{~Gy}$.

Due to the anatomy of perineum, the close urethra and anus there are crucial issues in treatment planning especially in recurrent vulvar cancer. Brachytherapy delivers a high dose of radiation strictly to the tumour while sparing the adjacent healthy tissues, because of rapid fall in dose outside the target. It brings about good cosmetic results with functional and anatomical organ preservation [13, 14], which is especially important among young women with vulvar cancer who suffer from severe psychological stress caused by hugely deforming surgery. It is estimated that about $15 \%$ of all vulvar cancers occur among young women [20] and the number is increasing $[1,3,4,21]$.

Recurrent disease is most frequently localized near the site of the primary lesion [17]. According to the li- 
terature, a recurrent vulvar cancer after radical surgery procedures occurs in $15-40 \%[6-8,22,23]$ of patients and more than $50 \%$ are localized in the vulvar area [6, 22]. In our patient both recurrences occurred on vulva, close to vulvectomy scar.

Failures usually occur during the first two years after initial surgical management $[7,17]$, but in some cases they may appear even five years or more after the primary treatment [7]. Sometimes three or more local recurrences are observed [6]. Some authors suggest that late failures may be a recurrent disease but also a second primary tumour and they often occur among patients with previously diagnosed vulvar lichen sclerosus [6]. Our patient had the first recurrence 5 years after the surgery and the second - 10 years after the previous treatment, both in different areas of vulva. Nicoletto et al. had $46 \%$ of the second local recurrences in his study [24], and Wooderlink et al. observed a second or further local failure in $72 \%$ of patients [6]. Our patient did not suffer from lichen sclerosus vulvae.

It is estimated that histological excision margin smaller than $8 \mathrm{~mm}$ is associated with a $50 \%$ rate of a local recurrence while a histological margin of $10 \mathrm{~mm}$ or greater is connected with a very low risk of failure [17]. In our study there was no pathology revision and therefore histological margins were not analyzed.

In our opinion, interstitial HDR brachytherapy among selected patients with a local recurrence of vulvar cancer is an effective and safe method which allows to preserve organ functions while providing good cosmetic results.

\section{References}

1. Saraiya $M$, Watson $M, W u X$, et al. Incidence of in situ and invasive vulvar cancer in the US, 1998-2003. Cancer 2008; 113 (10 suppl): 2865-72.

2. Jońska-Gmyrek J, Gmyrek L, Krynicki R i wsp. The role of radio-chemotherapy in the treatment of patients with advanced vulvar cancer. Prz Menopauz 2007; 6: 319-22.

3. Bodelon C, Madeleine MM, Voigt LF, Weiss NS. Is the incidence of invasive vulvar cancer increasing in the United States? Cancer Causes Control 2009; 20: 1779-82.

4. Judson PL, Habermann EB, Baxter NN, et al. Trends in the incidence of invasive and in situ vulvar carcinoma. Obstet Gynecol 2006; 107: 1018-22.

5. Witteveen PO, van der Velden J, Vergote I, et al. Phase II study on paclitaxel in patients with recurrent, metastatic or locally advanced vulvar cancer not amenable to surgery or radiotherapy: a study of the EORTC-
-GCG (European Organisation for Research and Treatment of Cancer Gynaecological Cancer Group). Ann Oncol 2009; 20: 1511-6.

6. Woolderink JM, de Bock GH, de Hullu JA, al. Patterns and frequency of recurrences of squamous cell carcinoma of the vulva. Gynecol Oncol 2006; 103: 293-299.

7. Gonzalez Bosquet J, Magrina JF, Gaffey TA, et al. Long-term survival and disease recurrence in patients with primary squamous cell carcinoma of the vulva. Gynecol Oncol 2005; 97: 828-33.

8. Lataifeh I, Nascimento MC, Nicklin JL, et al. Patterns of recurrence and disease-free survival in advanced squamous cell carcinoma of the vulva. Gynecol Oncol 2004; 95: 701-5.

9. Seeger AR, Windschall A, Lotter M, et al. The role of interstitial brachytherapy in the treatment of vaginal and vulvar malignancies. Strahlenther Onkol 2006; 182: 142-8.

10. Panek G, Gawrychowski K, Bidziński M i wsp. Przypadek skutecznego zastosowania plazmidowego wektora ekspresyjnego psFLT i chemioradioterapii do leczenia zaawansowanego miejscowo raka sromu. Prz Menopauz 2005; 4: 17-21.

11. Blake P. Radiotherapy and chemoradiotherapy for carcinoma of the vulva. Best Pract Res Clin Obstet Gynaecol 2003; 17: 649-61.

12. Hoffman M, Greenberg S, Greenberg H, et al. Interstitial radiotherapy for the treatment of advanced or recurrent vulvar and distal vaginal malignancy. Am J Obstet Gynecol 1990; 62: 1278-82.

13. Yamada T, Yanagawa S, Iwai H, et al. High-dose-rate interstitial brachytherapy of Bartholin's gland: A case report. Gynecol Oncol 2000; 77: 193-6.

14. Erak M, Mandić A, Baucal M, et al. Interstitial brachytherapy with 192Ir in vulvar cancer. Arcg Oncol 2006; 14: 52-3.

15. Tewari K, Cappuccini F, Syed AM, et al. Interstitial brachytherapy in the treatment of advanced and recurrent vulvar cancer. Am J Obstet Gynecol 1999; 181: 91-8.

16. Pohar S, Hoffstetter S, Peiffert D, et al. Effectiveness of brachytherapy in treating carcinoma of the vulva. Int J Radiat Oncol Biol Phys 1995; 32: 1455-60.

17. Baldwin P, Latimer J. Vulval cancer. Curr Obstet Gynaecol 2005; 15, 113-22.

18. Jolicoeur M, David S, Devieux A, et al. High dose brachytherapy as conservative treatment for vulvar cancer. Joint Brachytherapy Meeting GEC/ ESTRO-GLAC-ABS. Abstract. Radiother Oncol 2004; 71 (suppl 2): S133.

19. Frezza G, Baldissera A, Bernardi L, et al. Brachytherapy in vulvar cancer: Analysis of 18 patients. Radiother Oncol 1996; 39 (suppl. 1): S36.

20. Creasman WT, Phillips JL, Menck HR. The National Cancer Data Base report on early stage invasive vulvar carcinoma. The American College of Surgeons Commission on Cancer and the American Cancer Society. Cancer 1997; 80: 505-13.

21. Smith JS, Backes DM, Hoots BE, et al. Human papillomavirus type-distribution in vulvar and vaginal cancers and their associated precursors. Obstet Gynecol 2009; 113: 917-24.

22. Cavanagh D, Hoffman MS. Controversies in the management of vulvar carcinoma. Br J Obstet Gynaecol 1996; 103: 293-300.

23. Ulutin HC, Pak Y, Dede M. Can radiotherapy be a treatment option for elderly women with invasive vulvar carcinoma without radical surgery? Eur J Gynaecol Oncol 2002; 23: 426-8.

24. Nicoletto MO, Parenti A, Del Bianco P, et al. Vulvar cancer: prognostic factors. Anticancer Res 2010; 30: 2311-7. 